\title{
Penafsiran Tekstual dan Kontekstual terhadap al-Qur'ān dan Hadith (Kajian terhadap Muslim Salafi dan Muslim Progresif)
}

\begin{abstract}
Yusuf Rahman
Telaah atas buku karya Adis Duderija, Constructing a Religiously Ideal "Believer" and "Woman" in Islam: Neo-traditional Salafi and Progressive Muslims' Method of Interpretation, diterbitkan di New York oleh Palgrave Macmillan pada tahun 2011. 258 halaman. ISBN 978-0-230-12057-0
\end{abstract}

Buku ini berawal dari disertasi yang ditulis Adis Duderija di University of Western Australia. Sebenarnya beberapa bagian dari disertasi ini telah diterbitkan dalam bentuk artikel di beberapa jurnal, seperti Arab Law Quarterly, Journal of Muslim Minority Affairs, Hawwa, Islam and Christian - Muslim Relations, dll. Yang sangat prestisius adalah bahwa disertasi ini diterbitkan dalam Pelgrave Series in Islamic Theology, Law, and History yang diasuh Khaled Abou El Fadl, Guru Besar Hukum Islam di School of Law UCLA dan Ketua Program Pengkajian Islam di UCLA, yang karya-karyanya sangat penting dan otoritatif, serta sudah banyak diterjemahkan ke dalam Bahasa Indonesia.

Buku ini, menurut penelaah, ditulis untuk membuktikan bahwa perbedaan utama antara muslim Salafi, atau neo tradisional salafi (NTS), ${ }^{1}$ dengan muslim progresif (MP) terletak terutama pada perbedaan mereka dalam menggunakan metode penafsiran al-Qur'ān dan hadith. Yang pertama menggunakan pendekatan tekstual sementara yang kedua menggunakan pendekatan kontekstual. Kedua pendekatan inilah yang kemudian mempengaruhi bagaimana mereka menafsirkan tema-tema penting dalam Islam, seperti konsep orang beriman (believer/mu'min) dan perempuan (woman) yang ideal dalam Islam.

Di dalam mendefinisikan pendekatan tekstual dan kontekstual, penelaah merujuk kepada definisi dan klasifikasi yang diajukan Abdullah Saeed dalam

${ }^{1}$ Di dalam merujuk kepada kelompok Salafi, Duderija lebih banyak memilih istilah NTS walapun kelompok ini juga bisa disebut dengan Neo Ahl Hadith Salafism, karena kelompok ini menganut faham dan mazhab Ahl Ḥadith pada masa awal Islam. Lihat Duderija, Constructing a Religiously Ideal "Believer" and "Woman" in Islam (New York: Palgrave Macmillan, 2011), 49. 
karyanya Interpreting the Qur'ān: Towards A Contemporary Approach. ${ }^{2}$ Di dalam buku tersebut, Saeed menjelaskan bahwa kelompok tekstualis adalah mereka yang "argue for a strict following of the text and adopt a literalistic approach to the text." 3 Bagi mereka, al-Qur'ān-lah yang harus menjadi pegangan, walaupun kebutuhan dan konteks modern telah berubah dan berbeda dengan konteks ketika al-Qur'ān diturunkan. Akibatnya, bagi mereka, makna alQur'ān sudah jelas dan tetap yang harus diaplikasikan kapanpun dan di manapun. Sementara itu, kelompok kontekstualis, selain memperhatikan makna linguistik teks al-Qur'ān, menekankan pentingnya melihat konteks sosiohistoris pada masa pewahyuan al-Qur'ān (past context) dan juga konteks masa kini (present context), yang meliputi kesetaraan jender, HAM, globalisasi, dll. Jika kelompok tekstualis disebut oleh Saeed dengan Salafi atau Jihādi, maka kelompok kontekstualis dengan kelompok Ijtiha $\bar{a} \bar{i}^{4}$

Lebih jelas dan lengkapnya, ketika mengkaji metodologi penafsiran NTS dan MP, Duderija mendiskusikan dan membandingkan beberapa hal, di antaranya: bagaimana kedua kelompok ini melihat dan memperlakukan karakter dasar teks al-Qur'ān serta karakter dan fungsi bahasa dalam al-Qur'ān; bagaimana keduanya memberikan dan menemukan makna al-Qur'ān; bagaimana keduanya menggunakan rasio dan konteks dalam penafsiran; bagaimana keduanya menggunakan penafsiran tematik/tekstual dan penafsiran substansif dan maqāsidi $\bar{i}$ terhadap al-Qur'ān; serta bagaimana keduanya memperlakukan Sunnah Nabi. ${ }^{5}$

Berdasarkan atas kriteria-kriteria metodologis tersebut, dan dalam rangka membuktikan kesimpulannya di atas, Duderija menganalisis dan membandingkan karya-karya yang ditulis oleh kelompok NTS dan MP. Dari NTS, ia merujuk ke karya Nāșir al-Dīn al-Bānī, 'Abdullāh b. Bāz, Muhammad al-Madkhali dan Muhammad b. Uthaymin, serta beberapa pendukungnya di negara Barat, seperti Jamal Zarabazoo dan Bilal Philips. ${ }^{6}$ Sementara dari

2 Lihat Abdullah Saeed, Interpreting the Qur'ann: Towards a Contemporary Approach (New York: Routledge, 2006).

${ }^{3}$ Saeed, Interpreting the Qur'an, 3.

${ }^{4}$ Saeed, Interpreting the Qur'an, 3.

${ }^{5}$ Duderija, Constructing a Religiously Ideal "Believer" and "Woman" in Islam, 3-4.

${ }^{6}$ Duderija, Constructing a Religiously Ideal "Believer" and "Woman" in Islam, 3. Selain merujuk ke karya-karya mereka, Duderija juga menginformasikan bahwa karyakarya NTS dapat dikenali dan didapatkan dari beberapa percetakan yang memiliki kecenderungan Salafi, seperti Penerbit Tarbiyah di Toronto, Penerbit Salafi di Birmingham, Penerbit al-Khilafat di London, dan juga beberapa website, seperti www.salafipublications.com, www.tarbiyyahbookstore.com, www.qss.online.org, http://al-Sunna.com, www.salaf.com, www.fatwa-online.com, www.binbaz.org.sa, 
kelompok MP, ia merujuk ke karya-karya Khaled Abou El Fadl, Omid Safi, Farid Esack, Ebrahim Moosa, Kecia Ali, Amina Wadud. ${ }^{7}$ Di samping namanama terakhir, ia juga banyak merujuk kepada karya-karya Fazlur Rahman, Muḥammad Shạ̣rūr, Naṣr Ḥāmid Abū Zayd dan Muḥammad Arkūn.

Sebelum mendiskusikan dan membandingkan metode penafsiran dan penafsiran NTS dan MP tentang orang beriman dan perempuan dalam Islam, di Bagian Pendahuluan (Introduction) Duderija menjelaskan beberapa literatur yang sudah mengkaji tema tersebut, serta metodologi penafsiran yang mereka gunakana. Dalam "Review of Literature," ia merujuk dan mendiskusikan kelebihan dan kelemahan karya Amina Wadud, The Qur'an and Woman: Rereading the Sacred Text from a Woman's Perspective, ${ }^{8}$ Asma Barlas, Believing Women in Islam: Unreading Patriarchal Interpretations of the Qur'an, ${ }^{9}$ Farid Esack, Qur'an, Liberation and Pluralism: An Islamic Perspective of Interreligious Solidarity, ${ }^{10}$ dan Muhammad Shahrür, The Qur'an, Morality and Critical Reason: The Essential Muhammad Shahrur, serta dua karya Khaled Abou El Fadl, Speaking in God's Name: Islamic Law, Authority and Women, ${ }^{11}$ dan The Great Theft: Wrestling Islam from Extremists. ${ }^{12}$ Nampak sekali keberhutangan Duderija terhadap karya-karya tersebut, yang kebetulan adalah karya-karya kelompok MP, terutama kepada karya Abou El Fadl. Dalam hal ini, ia mengutip pernyataan Abou El Fadl:

www.rabee.net, www.ibnothaimeen.com. Lihat Duderija, Constructing a Religiously Ideal "Believer" and "Woman" in Islam, 50 dan 206, n. 10, 11, 12, 13, 14, 15.

7 Duderija, Constructing a Religiously Ideal "Believer" and "Woman" in Islam, 3. Nama-nama tersebut memang diakui termasuk ke dalam kelompok MP. Lihat tulisan mereka dalam buku yang diedit Omid Safi dengan judul Progressive Muslims: On Justice, Gender, and Pluralism (Oxford: Oneworld, 2003).

${ }^{8}$ Buku ini telah diterjemahkan ke Bahasa Indonesia dengan judul Quran Menurut Perempuan: Meluruskan Bias Jender dalam Tradisi Tafsir (Jakarta: Serambi Ilmu Semesta, 2001). Menarik untuk memperhatikan judul buku berbahasa Indonesia ini. Jika selama ini yang sering ditemukan judul-judul tafsir mawdị 'i, seperti Perempuan Menurut al-Qur'an, atau Perempuan Perspektif Al-Qur'an, yang kebetulan kebanyakan pengarangnya adalah laki-laki walaupun "mengatas namakan" (menurut/perspektif/wawasan) al-Qur'an, maka Wadud secara eksplisit dan sadar menyatakan bahwa karyanya atau penafsirannya ini menurut perspektif dia sebagai seorang perempuan.

9 Diterjemahkan ke bahasa Indonesia, Cara Quran Membebaskan Perempuan (Jakarta: Serambi, 2005).

10 Diterjemahkan ke bahasa Indonesia, Al-Quran, Liberalisme, Pluralisme: Membebaskan Yang Tertindas (Bandung: Mizan, 2000).

${ }^{11}$ Diterjemahkan ke bahasa Indonesia, Atas Nama Tuhan: Dari Fikih Otoriter ke Fikih Otoritatif (Jakarta: Serambi, 2004).

12 Diterjemahkan ke bahasa Indonesia, Selamatkan Islam dari Muslim Puritan (Jakarta: Serambi, 2006). 
"The meaning of religious texts are heavily affected by the moral and ethical predispositions and commitments made by the readers of those texts, but they are also affected by the technical tools that people use to understand the text. But this is not the place to get into the heuristic devices of puritans and moderats and the methods they use to unpack the meanings and implications of texts." 13

Duderija sependapat dengan Abou El Fadl bahwa makna teks sangat dipengaruhi moralitas pembacanya di samping juga metode yang digunakan pembacanya. Di dalam tulisannya yang lain, Abou El Fadl menulis

"Any text, including those that are Islamic, provides possibilities of meaning, not inevitabilities. And those possibilities are exploited, developed, and ultimately determined by the reader's efforts - good faith efforts, we hope - at making sense of the text's complexities. Consequently, the meaning of the text is often only as moral as its reader. If the reader is intolerant, hateful, or oppressive, so will be the interpretation of the text." 14

Jika karya Abou El Fadl belum menjelaskan metode penafsiran kedua kelompok tersebut, buku ini bagi Duderija adalah mengisi kekosongan dan melanjutkan apa yang tidak didiskusikan Abou El Fadl yaitu mendiskusikan metode interpretasi kedua kelompok ini, NTS dan MP, dan bagaimana metode tersebut mempengaruhi penafsiran mereka terhadap beberapa tema dalam alQur'ān. ${ }^{15}$

Setelah menjelaskan karya-karya yang dijadikannya sebagai sumber utama, metodologi yang digunakan dalam analisis, serta kajian pustaka terhadap literatur-literatur terdahulu, Duderija menyusun pembahasannya ke dalam tujuh bab. Pada Bab Pertama, Duderija menjelaskan genealogi kelompok NTS dan MP yang ditemukannya dalam kelompok ahl al-hadth dan madhhab atau ahl alra'y, Bab Kedua-Keempat membahas metode interpretasi NTS dan penafsiran mereka terhadap konsep "mu'min" dan "perempuan muslim," dan tiga bab

${ }^{13}$ Duderija, Constructing a Religiously Ideal "Believer" and "Woman" in Islam, 22, dengan merujuk karya Abou El Fadl, The Great Theft, 203.

${ }_{14}$ Abou El Fadl, The Place of Tolerance in Islam (New York: Beacon Press, 2002), $22-23$.

${ }^{15}$ Duderija, Constructing a Religiously Ideal "Believer" and "Woman" in Islam, 22. 
terakhir, Bab Kelima-Ketujuh membahas metode interpretasi MP dan juga penafsiran mereka. Buku ini ditutup dengan Penutup, di mana Duderija meringkas inti dari masing-masing bab.

Karya ini sangat penting untuk dimiliki dan dibaca, karena ia telah berhasil dengan sangat baik mendiskusikan metode penafsiran kedua kelompok ini dan pengaruh metode ini dalam memberikan makna terhadap beberapa tema dalam al-Qur'ān/Islam. Terutama, karya ini telah berusaha untuk merujuk kepada sumber-sumber utama dari tokoh NTS. Ia merujuk ke tokoh utama NTS, seperti Bin Baz, A Statement and Clarification of al-Salafiyyah: Concepts and Principals, Albanee, The Principals of the Salafee Methodology: An Islamic Manual for Reform, Al-Madkhalee, The Methodology of Ahlus Sunna Wal Jama'ah, dll. Memang akan lebih baik dan otoritatif jika merujuk ke karya mereka yang asli dalam bahasa aslinya, akan tetapi terjemahan karya-karya tersebut diterjemahkan dan diterbitkan oleh kelompok NTS sendiri.

Di dalam menganalisis dan membandingkan penafsiran dan metode penafsiran NTS dan MP, buku ini menggunakan metode block comparison, yaitu membandingkan perkelompok, di mana segala hal yang berkaitan dengan NTS dibahas di tiga bab pertama (Bab II-IV), dan yang terkait dengan MP di tiga bab terakhir (Bab V-VII). Metode perbandingan seperti ini ada kelebihan tapi juga ada kekurangannya. Kelebihannya, deskripsi dan analisis terhadap masing-masing kelompok lebih menyatu dan mengalir. Akan tetapi kekurangannya, persamaan dan perbedaan antara keduanya baru akan diketahui setelah membaca keseluruhan bab-bab tersebut.

Metode perbandingan yang lain adalah membandingkan antara keduanya dengan mengambil tema-tema persamaan dan perbedaan di masingmasing bab, seperti yang telah dilakukannya ketika membandingkan genealogi NTS dan MP di Bab I. Selanjutnya di Bab II misalnya, ia bisa membandingkan kelompok NTS dan MP serta metode penafsirannya, dan di Bab III membandingkan implikasi metode tersebut terhadap penafsiran konsep "mu'min" dan "perempuan muslim" yang ideal. Dengan metode seperti ini, titik perbedaan dan persamaan antara kedua kelompok tersebut akan lebih jelas sejak awal hingga akhir pembahasan.

Akhirnya, walaupun di dalam karyanya ini Duderija secara eksplisit tidak bermaksud untuk mendukung salah satu kelompok atas yang lain, ${ }^{16}$ namun

${ }^{16}$ Lihat Duderija, Constructing a Religiously Ideal "Believer" and "Women" in Islam, 2. "[I]t is not the intention of this study to advocate for preferability or superiority of one interpretative approach over the other but to identify and compare the assumptions governing the respective manahij and explain why they emerge." 
secara implisit dapat dipastikan bahwa ia lebih condong ke kelompok MP, karena di dalam analisisnya ia banyak sekali merujuk kepada karya-karya tokoh MP, dan juga dikarenakan karya ini diterbitkan dalam Pelgrave Series yang diasuh salah satu tokoh MP, Khaled Abou El Fadl, dan bukan diterbitkan oleh Penerbit Salafi. 